\title{
MODEL KOMUNIKASI MULTIKULTURAL MASYARAKAT JAWA PESISIR DENGAN MADURA DI DESA BUKO
}

\author{
Mahfudlah Fajrie
}

Fakultas Dakwah dan Komunikasi UNISNU Jepara, Jawa Tengah

Muhammad Nashrul Haqqi

Fakultas Dakwah dan Komunikasi UNISNU Jepara, Jawa Tengah mahfudlahfajrie@gmail.com

\section{Abstract}

Each region has a unique society that lies behind the existence of habits, language, communication models, and diverse worldviews. The interaction between two communities that have cultural distinctiveness is a multicultural phenomenon. One area representing the phenomenon is Buko Wedung Village, Demak Regency, where Javanese people as natives interact with Madurese immigrant communities. This study aims to find a multicultural communication model of the coastal communities of Java and Madura with Buko Village. This type of research is included in the field research with an ethnographic approach. Determination of informants is done by purposive sampling technique, while data collection is applied by observation, interviews, and documentation. Data were analyzed by a comparative approach, while the data validation process used triangulation techniques. Based on the results of research and data analysis, it was concluded that the multicultural communication model between the Javanese coastal communities and Madurese communities in Buko Village, Demak Regency, used the Gudykust and Kim model, a communication model that assumed two equal communication between each as a sender and receiver. This shows that cultural differences do not cause multicultural communities on the coast to lose their social relations. 
Al-Mishbah, Volume 14, Nomor 1, Januari-Juni 2018:

\section{Abstrak}

Setiap daerah memiliki kekhasan masyarakat yang melatarbelakangi adanya kebiasaan, bahasa, model komunikasi, dan pandangan dunia yang beragam. Interaksi antara dua komunitas yang memiliki kekhasan budaya merupakan fenomena multikultural. Salah satu wilayah merepresentasikan fenomena tersebut adalah Desa Buko Wedung, Kabupaten Demak, di mana masyarakat Jawa sebagai penduduk asli berinteraksi dengan masyarakat Madura pendatang. Penelitian ini bertujuan untuk menemukan model komunikasi multikultural masyarakat pesisir Jawa dengan Madura dengan Desa Buko. Jenis penelitian ini termasuk di dalam penelitian lapangan dengan pendekatan etnografi. Penentuan informan dilakukan dengan teknik purposive sampling, sedangkan pengumpulan data diterapkan dengan observasi, wawancara, dan dokumentasi. Data dianalisis dengan pendekatan komparatif, sementara proses validasi data menggunakan teknik triangulasi. erdasarkan hasil penelitian dan analisis data, disimpulkan bahwa model komunikasi multikultural antara masyarakat pesisir Jawa dan masyarakat Madura di Desa Buko, Kabupaten Demak, menggunakan model Gudykust dan Kim, model komunikasi yang mengasumsikan dua komunikasi yang sama antara masingmasing sebagai pengirim dan penerima. Hal ini menunjukkan bahwa perbedaan budaya tidak menyebabkan masyarakat multikultural di pesisir kehilangan relasi sosial mereka.

Kata kunci: model komunikasi, interaksi simbolik, multikultur, Jawa, Madura

DOI: 10.24239/al-mishbah.Vol14.Iss1.105 
M. Fajrie, M. N. Haqqi, Model Masyarakat Jawa Pesisir..

\section{A. Pendahuluan}

Setiap daerah memiliki masyarakat yang berbeda-beda (majemuk), dimana hal ini menjadikan masyarakat memiliki aktivitas yang beragam. Masyarakat pesisir, misalnya, cenderung bekerja sebagai nelayan, sedangkan masyarakat perkotaan sebagai pegawai dan pedesaan indentik sebagai petani. Selain memiliki aktivitas yang berbeda, karakter kebudayaan dan kepercayaan suatu daerah berbeda-beda antara masyarakat yang satu dengan yang lainnya. Dengan keberagaman masyarakat tersebut, dalam melakukan aktivitas masyarakat berkomunikasi melalui bahasa yang menunjang interaksi mereka. Namun pada umumnya, ragam interaksi bahasa yang digunakan berbeda-beda dikarenakan latar belakang budaya asal yang juga berbeda, misalnya seperti yang terjadi di daerah pesisir.

Wilayah pesisir di Pulau Jawa mempunyai masyarakat yang sangat majemuk dari segi budaya. Ada masyarakat Jawa tradisional, abangan, bahkan Madura. Masing-masing kebudayaan ini memiliki bahasa yang berbeda, sehingga keberagaman budaya komunikasi yang dilakukan oleh masyarakat pesisir juga mewakili keragamaan bahasa. Contohnya, masyarakat Jawa mempunyai stratifikasi bahasa Jawa, yakni ngoko, madya dan krama inggil, sedangkan masyarakat Madura juga mempunyai bahasa Madura enje'- iya, engghi-enten, dan engghi-bhunten dengan dialek yang bermacam-macam, seperti dialek Bangkalan, Sampang, Sumenep. Keberagaman budaya ini senantiasa mewarnai setiap kegiatan dan interaksi komunikasi di antara masyarakat pesisir yang berasal dari Jawa maupun Madura.

Hubungan komunikasi antar budaya mampu memberikan keuntungan dalam aktualiasasinya. Misalnya, terhadap peningkatan pengetahuan dan cara pandang seseorang tentang dunia melalui orang-orang baru dari budaya yang dijumpai, terjadi koordinasi antara budaya dengan komunikasi di tengah masyarakat. Fenomena ini dikenal dengan istilah fungsi komunikasi kultural (cultural 
communication function), yaitu budaya mempengaruhi komunikasi dan komunikasi mempengaruhi budaya. Dengan kata lain, budaya diciptakan, dibentuk, ditransmisikan, dan dipelajari melalui komunikasi.

Komunikasi yang dilakukan manusia dimaksudkan untuk melayani segala sesuatu. Akibatnya, komunikasi dalam kehidupan manusia menjadi proses yang universal. Komunikasi merupakan pusat dari seluruh sikap, perilaku, dan tindakan yang terampil dari manusia. Manusia dianggap melakukan interaksi sosial jika berkomunikasi dengan cara atau melalui pertukaran informasi, ideide, gagasan, serta emosi yang dinyatakan dengan simbol-simbol kepada orang lain. ${ }^{1}$

Komunikasi mempunyai fungsi untuk membangun konsep diri, aktualisasi diri, untuk kelangsungan hidup, memperoleh kebahagiaan, terhindar dari tekanan dan ketegangan, oleh sebab itu komunikasi harus menghibur dan dapat memupuk hubungan dengan orang lain. Oleh karena itu, aspek yang harus ditekankan adalah bagaimana komunikasi bisa berjalan efektif dan efisien dengan perbedaan latar belakang budaya dan bahasa dalam suatu lingkungan masyarakat agar pesan yang diterima dapat ditafsirkan secara sama antara komunikator dan komunikan. Hal ini menunjukkan bahwa komunikasi yang efektif terjadi tidak hanya saat seseorang telah melekatkan arti tertentu terhadap perilaku orang lain tetapi juga pada persepsi yang sesuai dengan pemberi pesan. Salah satu cara agar tidak terjadi salah persepsi adalah dengan menghindarkan pesan yang tidak jelas atau tidak spesifik serta dengan meningkatkan frekuensi umpan balik (feedback) guna mengurangi ketidakpastian dan tanda tanya dengan cara memahami bagaimana budaya

${ }^{1}$ Alo Liliweri, Dasar-Dasar Komunikasi antar Budaya (Yogyakarta: Pustaka Pelajar, 2002), 6. 
komunikasi dari lawan bicara, sehingga salah tafsir dari penyampaian pesan dapat dihindarkan.

Pemahaman terhadap budaya komunikasi mengharuskan pelaku komunikasi, terlebih dahulu, memahami kebudayaan. Budaya, menurut Edwart Burnett Tylor, $^{2}$ adalah kompleks dari keseluruhan pengetahuan, kepercayaan, kesenian, hukum, adat istiadat, dan setiap kemampuan lain dan kebiasaan yang dimiliki oleh manusia sebagai anggota suatu masyarakat. Budaya adalah suatu ekologi yang kompleks dan dinamis dari orang, benda, pandangan tentang dunia, kegiatan dan latar belakang (setting) yang secara fundamental bertahan lama tetapi juga berubah dalam komunikasi dan interaksi sosial yang rutin. Sedangkan komunikasi budaya adalah komunikasi yang dilakukan oleh beberapa orang atau kelompok yang berlatarbelakang budaya yang berbeda, sehingga dapat dikatakan komunikasi budaya adalah komunikasi antarbudaya (multikultural).

Hasil riset yang dilakukan Philep M. Regar dan Evelin Kawung menunjukkan bahwa pola komunikasi budaya yang terjadi antara etnis Sangihe dengan Taulud Sitaro adalah primer dan sirkular, sedangkan identitas etnik terdapat perbedaan antara orang tua dan anak muda. ${ }^{3}$ Orang tua masih aktif menggunakan bahasa daerah sedangkan anak muda sudah berkurang, terutama mereka yang mempunyai orang tua yang berbeda etnik. Demikian juga dengan pemaknaan dan keaktifan dalam acara, orang tua yang dinilai mampu memaknai acara dengan mendalam dibandingkan dengan anak muda yang mempersepsikan suatu acara dari sisi keramaiannya. Temuan ini menunjukkan bahwa komunikasi antar budaya sangat penting bagi kehidupan dan ilmu pengetahuan agar

\footnotetext{
2 Ibid., 107.
}

${ }^{3}$ Philep M. Regardan Evelin Kawung, Pola Komunikasi Antarbudaya dan Identitas Etnik Sangihe-Taulud Sitaro, Journal Acta Diurna 3, no.4, 2014, 1-10. 
masyarakat dapat memahami komunikasi antar budaya yang berbeda-beda.

Penelitian Hedi Heryadi dan Hana Silvana tentang komunikasi antar budaya dalam masyarakat multikultur, yaitu masyarakat migran Sundan di Permu Bengkulu memperlihatkan adanya adaptasi timbal balik antara etnis Sunda sebagai pendatang dengan etnis Rejang sebagai pribumi. Adanya sikap saling menghargai dan menghormati antara etnis pendatang dan pribumi memungkinkan setiap kelompok etnis tersebut untuk menjalankan kebudayaannya masing-masing. Saat berdialog, masyarakat dari etnis Sunda dan Rejang dapat menggunakan bahasa Sunda, bahasa Rejang, atau bahasa Melayu dialek Bengkulu. ${ }^{4}$ Hubungan antara kedua etnis tersebut sejauh ini telah berlangsung tanpa hambatan yang berarti karena masingmasing etnis telah saling menerima apa adanya. Penjelasan di atas menunjukkan bahwa komunikasi multikultural yang terjadi di beberapa daerah belangsung dengan baik dan saling menghormati.

Hasil-hasil penelitian yang pernah dilakukan terkait komunikasi multikultural seringkali membahas komunikasi multikultural masyarakat luar pulau Jawa. Temuan ini menunjukkan perlunya kajian komunikasi multikultural di Jawa, mengingat masyarakat Jawa merupakan kelompok kebudayaan yang dominan di Indonesia. Keragaman budaya yang ada disuatu daerah memunculkan budaya komunikasi yang berbeda pula. Hal ini tampak di Desa Buko Kecamatan Wedung Kabupaten Demak. Desa Buko merupakan salah satu desa pesisir di Kecamatan Wedung dengan luas wilayah 6,59 kilo meter persegi dan jumlah penduduk 3.962 orang.

Berdasarkan observasi awal, di Desa Buko terdapat dua bahasa yang berbeda. Bahasa ini berasal dari masyarakat dengan latar

${ }^{4}$ Hedi Heryadidan Hana Silvana, Komunikasi Antarbudaya dalam Masyarakat Multikultur (Studi tentang Adaptasi Masyarakat Migran Sundan di Desa Imigran Permu Bengkulu), Jurnal Kajian Komunikasi 1, no. 1, 2013, 95-108. 
belakang kebudayaan yang berbeda, yaitu masyarakat Jawa pesisir (pribumi) dan masyarakat Madura sebagai pendatang. Dalam kesehariannya, masyarakat Jawa dan Madura berinterkasi dan berkomunikasi, meskipun masyarakat Madura mempunyai dialek bahasa yang berbeda dengan orang Jawa. Komunikasi ini berlangsung di wilayah pesisir yang identik dengan lingkungan yang panas, kasar, dan lugas dalam berbicara. Keberadaan dua budaya yang hidup dalam satu wilayah tentunya meniscayakan adanya proses asimilasi budaya. Akan tetapi, model interaksi komunikasi yang terjadi antara masyarakat Jawa pesisir sebagai pribumi dan masyarakat Madura sebagai pendatang belum menjadi perhatian para pengkaji di bidang komunikasi. Oleh sebab itu, penelitian ini bermaksud untuk menganalisa model komunikasi multikultural antara masyarakat Jawa dan Madura di Desa Buko Kabupaten Demak.

\section{B. Kerangka Teoritis}

Penelitian ini menggunakan teori interaksi simbolik milik Herbert Blumer. Esensi dari teori Blumer menetapkan bahwa aktivitas yang merupakan ciri khas manusia. Komunikasi atau pertukaran simbol mengkonseptualisasikan manusia sebagai pencipta atau pembentuk kembali lingkungannya. ${ }^{5} \quad$ Interaksionisme simbolik mempelajari sifat interaksi yang merupakan kegiatan sosial dinamis manusia. Dalam perspektif ini, individu bersifat aktif, reflektif, dan kreatif. Oleh karena individu terus berubah, maka masyarakat turut berubah melalui interaksi.

Teori interaksi simbolik yang digunakan dalam penelitian ini berusaha memahami perilaku manusia dari sudut pandang subyek, yaitu perilaku manusia yang harus dilihat sebagai proses yang memungkinkan manusia membentuk dan mengatur perilakunya dengan mempertimbangkan keberadaan orang lain yang menjadi

${ }^{5}$ Alex Sobur, Semiotika Komunikasi (Bandung: Remaja Rosdakarya, 2004), 194. 
mitra interaksinya. Pada intinya, interaksi dianggap sebagai variabel penting dalam menentukan perilaku manusia. Pemahaman terhadap diri sendiri serta pertukaran pesan yang dikirimkan dan diterima akan lebih baik melalui percakapan dengan orang lain. ${ }^{6}$

Secara ringkas, teori interaksi simbolik didasarkan pada premispremis berikut. ${ }^{7}$ Pertama, individu merespons suatu situasi simbolik, merespons lingkungan termasuk obyek fisik (benda) dan obyek sosial (perilaku manusia). Kedua, makna adalah produk interaksi sosial. Oleh karena itu makna tidak dilihat pada obyek melainkan dinegosiasikan melalui penggunaan bahasa. Dan, yang ketiga, makna yang diinterpretasikan individu dapat berubah dari waktu ke waktu sejalan dengan perubahan situasi dalam interaksi sosial. Kesimpulannya adalah bahwa interaksi simbolik adalah sebuah kerangka referensi untuk memahami bagaimana manusia bersama dengan orang lain membentuk perilaku manusia. Dengan fokus pada pola komunikasi, pehatian utama yang dieksplorasi dalam penelitian ini adalah interaksi sosial masyarakat Jawa pesisir sebagai masyarakat pribumi dengan masayarakat Madura sebagai pendatang di Desa Buko Kecamatan Wedung Kabupaten Demak, di mana interaksi sosialnya dapat ditemukan di dalam akulturasi budaya.

\section{Metode Penelitian}

Lokasi penelitian ini terletak di Desa Buko yang berada di wilayah pesisir Kecamatan Wedung, Kabupaten Demak. Subyek penelitian adalah masyarakat di desa tersebut yang terdiri dari etnis Jawa dan Madura. Jenis penelitian ini adalah penelitian lapangan (field research) dengan pendekatan etnografis yang termasuk dalam

${ }^{6}$ Richard Westdan Turner Lynn H, Pengantar Teori Komunikasi: Analisis dan Aplikasi Buku 1, Terj. Maria Natalia Damayanti Maer (Jakarta: Salemba Humanika, 2008), 93.

${ }^{7}$ Alex Sobur, Semiotika Komunikasi (Bandung: Remaja Rosdakarya, 2004), 199. 
jenis penelitian kualitatif. Metode etnografi adalah prosedur penelitian kualitatif yang bertujuan untuk menggambarkan, menganalisa, dan menafsirkan unsur-unsur dari sebuah kelompok budaya, seperti pola perilaku, kepercayaan, dan bahasa yang berkembang dari waktu ke waktu.

Fokus penelitian ini adalah model komunikasi multikultural. Dalam penerapannya, penelitian ini melakukan pengumpulan, penggolongan atau pengklasifikasian, dan analisis terhadap model komunikasi multikultural masyarakat Jawa dan Madura di Desa Buko. Sejalan dengan hal tersebut, obyek penelitian adalah interaksi sosial, proses komunikasi, dialek, dan bahasa yang digunakan dalam komunikasi antara masyarakat Jawa dan Madura, sehingga dapat ditemukan model komunikasi masyarakat di kawasan pesisir Pulau Jawa.

Data dalam penelitian ini dibagi ke dalam dua jenis, yaitu data primer dan sekunder. Data primer diperolah melalui catatan tertulis atau melalui alat perekam video atau audio dan pengambilan foto. Peneliti melakukan wawancara dengan beberapa penduduk asli dan pendatang Desa Buko yang berasal dari etnis Jawa dan Madura. Sistem pengambilan respondennya dengan teknik purposive sampling, yakni teknik pengumpulan data dengan pertimbangan tertentu. Pengambilan data yang didahului pertimbangan peneliti yang ditindaklanjuti dengan pengamatan serta wawancara. Para responden penelitian ini adalah tokoh masyarakat, tokoh agama, dan masyarakat setempat Desa Buko. Adapun data sekunder dalam penelitian ini berupa data tertulis yang berasal dari jurnal ilmiah dan buku-buku referensi komunikasi antar budaya. Setelah data dikumpulkan, pemeriksaan keabsahan data dilakukan dengan teknik triangulasi data atau triangulasi sumber.

Dalam penelitian ini, data model komunikasi masyarakat Jawa dan Madura yang terkumpul dibandingkan, sehingga dapat ditemukan persamaan dan perbedaan yang membuat etnis tersebut 
dapat berinteraksi. Melalui perbandingan ini, pada akhirnya, dapat ditemukan model komunikasi multikultural antara masyarakat Jawa dan Madura di pesisir Pulau Jawa.

\section{Hasil Penelitian dan Pembahasan}

\section{Komunitas Masyarakat Madura di Desa Buko}

Desa Buko termasuk desa yang padat penduduk dikarenakan karakter penduduk Desa Buko yang sangat terbuka kepada masyarakat untuk masuk ke desanya. Di Desa Buko terdapat bermacam-macam penduduk yang sering disebut sebagai masyarakat pendatang, seperti penduduk yang berasal Madura. Hal ini menjadi menarik untuk dianalisis, mengingat masyarakat Madura menjadi salah satu pendatang yang cukup banyak di Desa Buko. Salah satu alasan masyarakat Madura berpindah tempat (sebagai pendatang) ke Desa Buko adalah untuk mencari pekerjaan dan rata-rata menjadi pedagang ataupun bergerak di bidang jasa.

Desa Buko merupakan salah satu desa yang berada di Kecamatan Wedung Kabupaten Demak. Lokasinya berdampingan dengan Desa Wedung yang merupakan jantung Kecamatan, Buko merupakan salah satu desa dengan taraf ekonomi yang cukup maju, hal tersebut dapat dilihat dari keadaan lingkungan dan juga infrastrukturnya yang cukup bagus. Selain dari bangunannya, sumber daya manusianya juga cukup baik, hal tersebut dapat dibuktikan berdasarkan data yang telah penulis paparkan di atas selain itu perkembangan Desa Buko terlihat dari banyaknya warga pendatang dari berbagai wilayah, diantaranya warga Madura, Lamongan, Solo, Bandung dan lainnya. Dari beberapa warga pendatang, tidak jarang pula yang akhirnya menikah dengan orang pribumi, yakni masyarakat asli Desa Buko Kecamatan Wedung Kabupaten Demak dan akhirnya hidup berkeluarga di desa tersebut.

Mengingat posisi geografis Desa Buko yang berada di pesisir, sebagian besar warga setempat bekerja sebagai nelayan. Selain menjadi nelayan, terdapat juga masyarakat yang menjadi pengusaha 
mebel yang memproduksi perahu sebagai sarana masyarakat untuk bekerja di laut. Melihat peluang dari warganya yang banyak menjadi nelayan dan membutuhkan perahu, hal tersebut menjadikan peluang bagi pengusaha mebel.

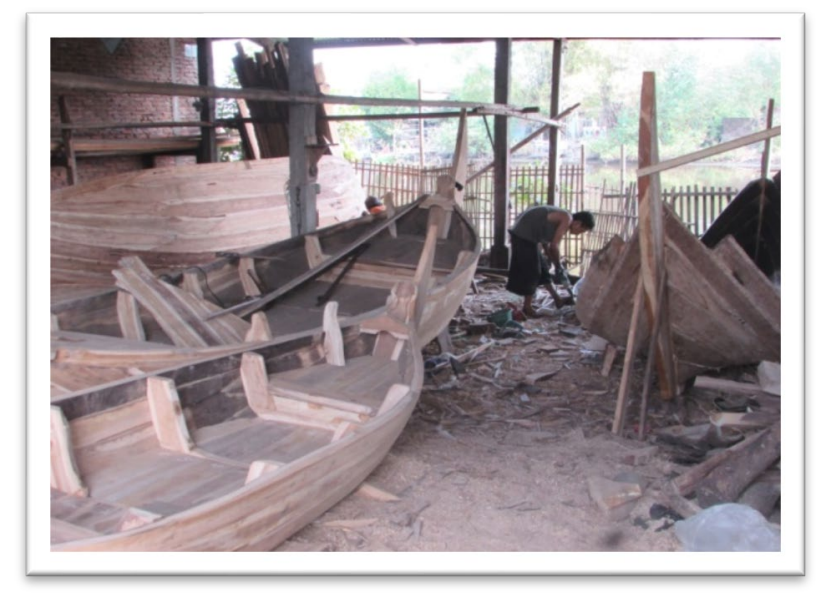

\section{Gambar 1}

Usaha Pembuatan Perahu di Desa Buko

Selain menjadi nelayan, pembuatan mebel perahu, terdapat pula masyarakat Desa Buko yang bekerja sebagai pedagang. Desa Buko memang terlihat sangat ramai dan banyak pedagang yang menggelar lapak di pinggir jalan. Pedagang tersebut bukan hanya berasal dari warga sekitar Kecamatan Wedung, melainkan banyak yang dari luar daerah, salah satunya warga Madura yang cukup banyak memadati Desa Buko. Mereka, pada umumnya, berprofesi sebagai penjual sate, penjual bubur kacang hijau, penjual nasi goreng dan juga tukang cukur atau salon Madura.

Dari sekian banyak warga pendatang, warga Madura yang terlihat paling menonjol dan cukup banyak di Desa Buko adalah komunitas Madura yang disebut Sakera. Nama ini diambil dari nama tokoh pejuang Madura yang cukup popular di zaman penjajahan Belanda dan sangat disegani oleh masyarakat Madura. Masyarakat Madura menyebutnya Mbah 
Sakera, yakni sosok pemberani dan bersuara lantang, yang sering membawa senjata berupa celurit.

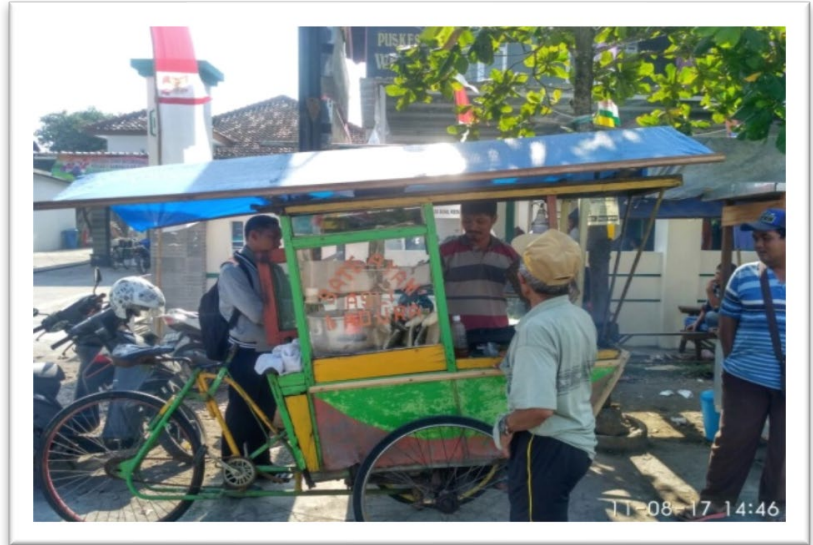

Gambar 2

Penjual Sate Madura di Desa Buko

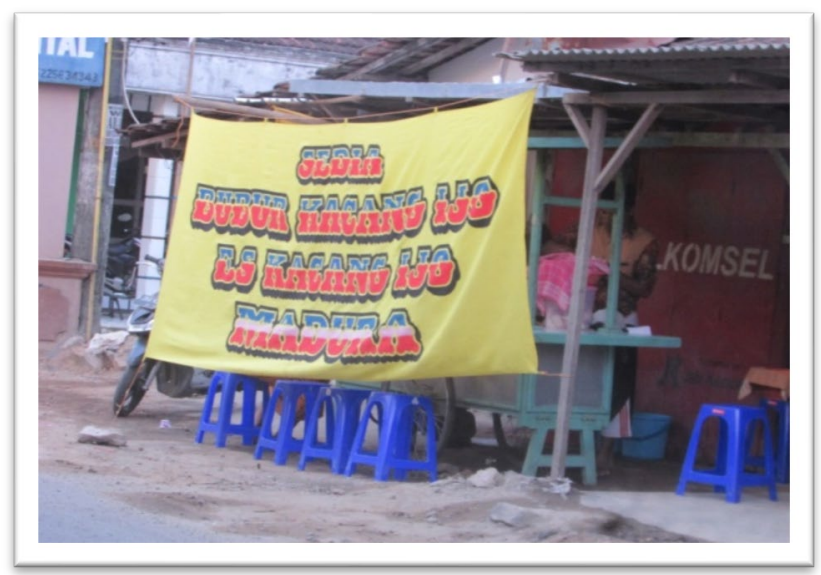

Gambar 3

Penjual Bubur Kacang Hijau Madura di Desa Buko

Komunitas Sakera dibentuk dari lingkup desa, kecamatan, kabupaten, provinsi hingga tingkat nasional. Di Desa Buko juga terdapat komunitas Sakera yang beranggotakan tidak lebih dari 15 orang, namun biasa berkumpul dengan anggota lain dalam lingkup kecamatan yang beranggotakan lebih dari 50 orang. Setiap tahun, ketika Hari Raya Idul Adha, mereka berkumpul di Madura. Semua 
komunitas berkumpul hingga menyebabkan kemacetan di sepanjang jalan. Bagi penduduk Madura, kegiatan tersebut bermanfaat bagi warga perantau, karena dapat mempererat hubungan persaudaraan dan kekeluargaan.

Warga Madura di Desa Buko merupakan salah satu penduduk pendatang yang bertempat tinggal dan bekerja. Masyarakat Madura biasa berkumpul setiap 20 hari sekali. Selain rutinitas itu, setiap hari Kamis atau malam Jumat digelar perkumpulan khusus bagi masyarakat Madura dengan kegiatan istigasah dari rumah satu ke rumah lain. Seperti perkumpulan Sakera di setiap Hari Raya Idul Adha, rutinitas masyarakat Madura di Desa Buko dilakukan dengan tujuan untuk menjaga solidaritas dan kerukunan sesama warga Madura di perantauan.

\section{Interaksi Sosial Masyarakat Jawa dan Madura di Desa Buko}

Interaksi sosial merupakan merupakan salah satu bentuk komunikasi setiap manusia, salah satunya warga Jawa dan Madura di Desa Buko, Kecamatan Wedung, Kabupaten Demak. Toleransi dan kerukunan kedua etnis tersebut tampak terjalin cukup baik. Fenomena tersebut dapat dibuktikan dari beberapa hal yang dilakukan setiap hari, di antaranya pada kegiatan desa, seperti pada kegiatan pengajian umum dan swadaya masyarakat. Warga Desa Buko juga terlihat membaur ketika mengikuti kegiatan pengajian yang ada di masjid ataupun musholla setempat. Sedangkan dalam konteks swadaya masyarakat, bukan hanya warga beretnis Jawa yang menjadi pribumi terlibat dalam swadaya, namun semua warga, baik pendatang maupun warga pribumi bahu membahu bersamasama. Dalam kedua momentum di atas, etnis Jawa dan Madura saling berinteraksi dan menjalin toleransi serta kerukunan yang baik.

Desa Buko juga memiliki pasar yang mana bisa menjadi pusat proses interaksi melalui transaksi jual beli. Pasar desa tersebut tidak hanya dipadati oleh masyarakat setempat saja, melainkan juga 
dipenuhi masyarakat yang berasal luar Desa Buko, seperti Desa Bungo, Desa Wedung, dan sekitarnya. Dalam proses jual beli di pasar pagi Desa Buko, warga pribumi (Jawa) lebih banyak sebagai pedagang, sedangkan warga Madura (pendatang) sebagai pembeli. Selain memiliki pasar tradisional, masyarakat Desa Buko juga mempunyai Tempat Pelelangan Ikan (TPI), mengingat mayoritas warganya merupakan nelayan.

Menurut Ketua Karang Taruna setempat, Sirojudin, masyarakat di Desa Buko tidak tersegmentasi akibat perbedaan status sosial maupun suku. Selama mereka mentaati aturan yang ada di desa tersebut dan berbaur dengan masyarakat, tidak akan ada masalah dalam interaksi sosial. Bila warga pendatang mengasingkan diri, masyarakat setempat akan merangkul dengan cara mengajak bergabung bersama pengajian rutinan di masjid dan di tempattempat lainnya. ${ }^{8}$ Keanekaragaman kelompok sosial di Desa Buko tetap membuat masyarakat setempat dapat hidup nyaman, karena mentaati berbagai norma-norma sosial, seperti menjaga kerukunan antar umat Islam meskipun berbeda serta menciptakan keharmonisan hubungan antar sesama dengan mentaati hukum yang ada pada Desa Buko dan Kecamatan Wedung. Adanya hubungan baik di antara etnis Jawa dan Madura tidak lain karena tumbuhnya kepekaan sosial masyarakat yang ada di Desa Buko akibat intensitas interaksi antar komunitas yang terbina melalui beragam aktifitas yang telah dikemukakan di atas.

\section{Model Komunikasi Masyarakat Jawa dan Madura di Desa Buko}

Interaksi yang baik antara penduduk etnis Jawa dan Madura di Desa Buko dalam konteks relasi sosial turut berdampak pada relasi personal antar kedua etnis ini, hingga tidak sedikit masyarakat

${ }^{8}$ Sirojudin. Wawancara oleh penulis. Perekam ponsel. Desa Buko, 7 Agustus 2017. 
Madura yang menetap di Desa Buko dikarenakan hubungan pernikahan dengan masyarakat Jawa setempat. Dengan adanya perkawinan antar masyarakat yang berbeda budaya, interaksi dan komunikasi yang terjadi di Desa Buko antar pribumi dan pendatang ikut terjalin dengan baik.

Komunikasi antara Jawa dan Madura menunjukkan model yang cukup efektif. Pada umumnya, kedua komunitas etnis ini menggunakan bahasa Indonesia sebagai medium alternatif dalam berkomunikasi. Meskipun telah lama tinggal di Desa Buko, logat dan gaya bahasa warga Madura masih sangat kental dengan bahasa asli mereka. Ketika berkomunikasi dengan keluarga sendiri di dalam rumah, warga Madura masih menggunakan bahasa Madura. Ratarata masyarakat Madura bisa menggunakan bahasa Jawa, walau terbatas pada beberapa kata-kata yang lazim dan sering digunakan dalam berkomunikasi. Dengan demikian, warga Madura yang berada di Desa Buko belum fasih dan paham tentang bahasa Jawa. Realitas ini berbeda dalam kasus warga etnis Madura yang telah menikah dengan orang Jawa, di mana dialek khas bahasa Madura tampak pudar dan bahkan sangat fasih dalam berbahasa Jawa. Berdasarkan temuan, terdapat perbedaan antar masyarakat Madura yang berstatus pendatang di Desa Buko: unsur bahasa etnis tidak terlihat pada warga etnis Madura yang telah menikah dengan orang Jawa, sedangkan yang tidak menikah dengan orang pribumi memiliki bahasa Madura masih terjaga.

Observasi dan wawancara dengan etnis Madura di Desa Buko menunjukkan bahwa komunikasi mereka bergantung pada lawan bicara atau komunikatornya, yaitu, bila komunikator berbahasa Jawa, komunikan akan menjawab dengan bahasa Jawa yang bercampur dengan bahasa Indonesia. Namun, jika komunikator menggunakan bahasa Indonesia, maka mereka menjawab dengan bahasa Indonesia, sedangkan kepada sesama warga beretnis Madura mereka menggunakan bahasa Madura. 
Faktor bahasa merupakan bagian penting komunikasi antar masyarakat Jawa dan Madura di Desa Buko, terutama sebagai penunjang keberhasilan maupun kegagalan komunikasi. Kebudayaan yang bersifat personal bukan merupakan hambatan dalam komunikasi antara masyarakat Jawa dan Madura di Desa Buko. Pesan yang disampaikan dapat sampai pada komunikannya. Hal ini berbeda dengan komunikasi masyarakat pesisir Desa Buko, baik Jawa maupun Madura ketika menjalin komunikasi dengan orang asing atau masyarakat luar wilayah Desa Buko. Tidak jarang informasi atau pesan yang diterima berbeda antara komunikator dan komunikan. Kenyataan ini dipengaruhi oleh kondisi geografis, seperti iklim, situasi dan persepsi orang asing atau luar wilayah Desa Buko terhadap masyarakat pesisir. Berdasarkan pengamatan peneliti, komunikasi yang terjadi antara masyarakat Jawa dan Madura di Desa Buko adalah komunikasi interpersonal dan cenderung terjadi timbal balik, sehingga interaksi sosial antar kedua masyarakat tersebut terjalin dengan baik.

Model komunikasi merupakan alat untuk menjelaskan atau untuk mempermudah penjelasan komunikasi. Dalam pandangan Sereno dan Mortensen, ${ }^{9}$ model komunikasi merupakan deskripsi ideal mengenai apa yang dibutuhkan untuk komunikasi. Oleh karena itu, model bisa disebut sebagai gambaran informal untuk menjelaskan atau menerapkan teori atau penyederhanaan teori. Fungsi model komunikasi paling tidak bisa melukiskan proses komunikasi, menunjukkan hubungan visual, dan membantu dalam menemukan dan memperbaiki kendala komunikasi dalam persepsi teoritik.

Berdasarkan pengamatan terhadap model komunikasi di wilayah Desa Buko, ditemukan bahwa model komunikasi yang terjadi antara masyarakat Jawa dan Madura di desa tersebut selaras

${ }^{9}$ Dedy Mulyana, Metode Penelitian Kualitatif (Bandung: PT. Remaja Rosdakarya, 2001), 121. 
dengan model komunikasi Gudykunst dan Kim. Model komunikasi antar budaya Gudykunst dan Kim adalah komunikasi antara orangorang yang berasal dari budaya berlainan atau komunikasi dengan orang asing (stranger). ${ }^{10}$ Komunikasi ini pada dasarnya dilakukan melalui tatap muka, khususnya antara dua orang. Hal yang sama dilakukan oleh masyarakat Jawa dan Madura di Desa Buko dalam berkomunikasi, di mana mereka cenderung berkomunikasi secara tatap muka. Walaupun terkadang faktor bahasa menjadi penghalang, kelincahan dalam berkomunikasi membuat pesan yang disampaikan dapat dipahami antar satu dengan yang lain. Hal ini menjadikan interaksi sosial antar masyarakat Jawa dengan Madura terjalin baik dan membentuk kerukunan antar sesama di desa.

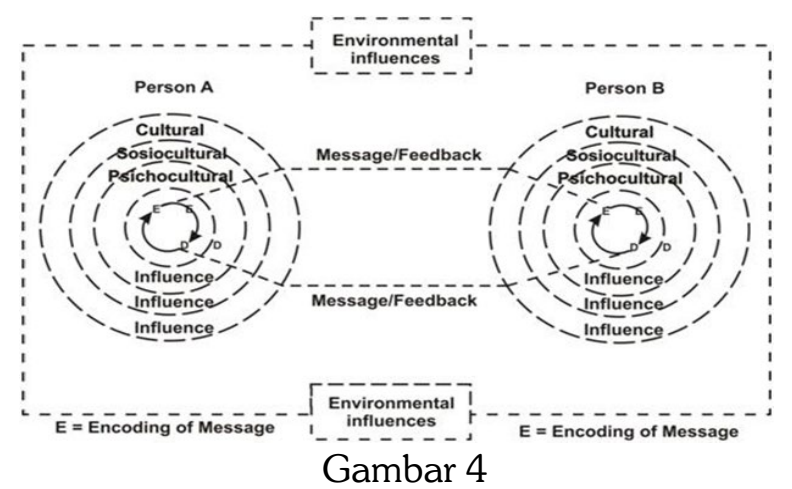

Model Komunikasi Masyarakat Jawa-Madura Berdasarkan Model Gudykunst dan Kim

Model komunikasi Gudykunst dan Kim ini mengasumsikan dua orang yang setara dalam berkomunikasi, masing-masing sebagai pengirim dan sekaligus sebagai penerima, atau keduanya sekaligus melakukan penyandian (encoding) dan penyandian balik (decoding). Intinya, komunikator dan komunikan berkomunikasi secara serentak sekaligus, di saat yang sama, melakukan penyandian dan penyandian balik pesan. Dengan kata lain, komunikasi bukan proses yang statis.

${ }^{10}$ DedyMulyana, Ilmu Komunikasi Suatu Pengantar (Bandung: PT. Remaja Rosdakarya, 2009), 171. 
Menurut Gudykunst dan Kim, penyandian pesan dan penyandian balik dari pesan merupakan proses interaktif yang dipengaruhi oleh filter-filter konseptual yang dikategorikan menjadi faktor-faktor budaya, sosiobudaya, psikobudaya, dan faktor lingkungan. Hal ini terlihat di Desa Buko, bahwa komunikasi yang terjadi antara masyarakat Jawa dan Madura di wilayah tersebut turut dipengaruhi oleh faktor budaya, sosiobudaya, psikobudaya, dan lingkungan. Masyarakat Madura sebagai pendatang di Desa Buko dapat diterima dan berinteraksi dengan baik dikarenakan mampu melakukan penyandian dan penyandian balik dalam berkomunikasi dengan masyarakat Jawa maupun lainnya di Desa Buko.

Salah satu unsur yang melengkapi model Gudykunst dan Kim adalah lingkungan. Lingkungan memberikan pengaruh dalam proses penyandian dan penyandian balik pesan. Lokasi geografis, iklim, situasi arsitektural (lingkungan fisik), dan persepsi atas lingkungan tersebut, mempengaruhi cara dalam menafsirkan rangsangan yang datang dan prediksi yang dibuat mengenai perilaku orang lain.

Dalam model Gudykunst dan Kim dijelaskan bahwa faktor lingkungan seperti lokasi geografis dan iklim dapat mempengaruhi dalam berkomunikasi, hal inilah yang menyebabkan budaya komunikasi masyarakat Jawa dan Madura di Desa Buko lugas, lantang, dan apa adanya, sehingga masyarakat luar wilayah pesisir sering menafsirkan bahwa komunikasi masyarakat pesisir cenderung kasar dan tampak sedang dalam kondisi marah.

Model komunikasi Gudykunst dan Kim yang menekankan perhatian kepada kondisi geografis, iklim, dan sosiobudaya memperlihatkan bahwa perbedaan etnis tidak menjadi penghalang dalam komunikasi antara warga di Desa Buko. Perbedaan etnis dan bahasa antar penduduk Jawa dan Madura di Desa Buko tidak menjadi hambatan komunikasi di antara keduanya oleh kesamaan lingkungan dan iklim yang melatari proses komunikasi. Dalam hal ini, masyarakat Jawa yang merupakan penduduk asli di Desa Buko 
memiliki kesamaan karakter dengan penduduk yang berasal dari pulau Madura sebagai komunitas yang mukim di pesisir. Masyarakat Madura yang, pada awalnya, merupakan second people di Desa Buko, secara statistik mengalami kenaikan jumlah dan menjadi salah satu bagian penggerak ekonomi desa.

\section{E. Kesimpulan}

Model komunikasi multikultural antara masyarakat Jawa dengan Madura di Desa Buko adalah menggunakan model Gudykunst dan Kim, yakni model komunikasi yang mengasumsikan dua orang yang setara dalam berkomunikasi, masing-masing sebagai pengirim dan sekaligus sebagai penerima atau keduanya sekaligus, melakukan penyandian (encoding) dan penyandian balik (decoding). Proses interaksi dalam penyandian dan penyandian balik dipengaruhi oleh faktor budaya, sosiobudaya, psikobudaya, dan faktor lingkungan. Adanya kesamaan lingkungan geografis dan iklim antara wilayah Desa Buko dengan pulau Madura telah menyebabkan masyarakat Madura sebagai pendatang mampu beradaptasi dengan cepat dan berkomunikasi dengan baik, sehingga masyarakat Madura dapat diterima dan menjadi bagian integral masyarakat di Desa Buko.

\section{Daftar Pustaka}

Burgoon, Michael. Approaching Speech/Communication. New York: Holt, Rinehart \& Winston, 1974.

Civikly, Jean M. Messages: A Reader in Human Communication. New York: Random House, 1974.

Creswell, John W. Qualitative Inquiry And Research Design: Choosing Among Five Traditions. London: SAGE Publications, 1998.

DeFleur, Melvin L. Theories of Mass Communication. New York: David McKay, 1970. 
DeVito, Joseph A. Komunikasi Antarmanusia: Kuliah Dasar. Edisi ke5. Terj. Agus Maulana. Jakarta: Professional Books, 1997.

Gudykunst, William B dan Young Kim. Communicating with Strangers: An Approach to Intercultural Communication. New York: McGraw-Hill, 1992.

Heryadi, Hedi dan Silvana, Hana. "Komunikasi Antarbudaya dalam

Masyarakat Multikultur (Studi tentang Adaptasi Masyarakat

Migran Sundan di Desa Imigran Permu Bengkulu)". Jurnal Kajian Komunikasi 1, no.1, 2013.

Horton, Paul B \& Chester L. Hunt. Sosiologi Jilid I. Jakarta: Erlangga, 1991.

Koentjaraningrat. Metode-metode Penelitian Masyarakat. Jakarta: PT. Gramedia Pustaka Utama, 1993.

. Manusia dan Kebudayaan di Indonesia. Jakarta:

Djambatan, 1990.

Kusnadi. Konflik Sosial Nelayan. Yogyakarta: LkiS, 2002.

Liliweri, Alo. Dasar-dasar Komunikasi Antarbudaya. Yogyakarta:

Pustaka Pelajar, 2002. . Makna Budaya dalam Komunikasi Antar Budaya.

Yogyakarta: PT LkiS Printing Cemerlang, 2009.

Moleong, Lexy. Metodologi Penelitian Kualitatif. Bandung: PT. Remaja Rosdakarya, 2014.

Mulyana, Dedy. Metode Penelitian Kualitatif. Bandung: PT. Remaja Rosdakarya, 2001. . Ilmu Komunikasi Suatu Pengantar. Bandung: PT. Remaja Rosdakarya, 2009.

Redfield, Robert. The Little Community and Peasant Society and Culture. Chicago: The University of Chicago Press, 1963.

Regar, Philep M. dan Kawung, Evelin. "Pola Komunikasi Antarbudaya dan Identitas Etnik Sangihe-Taulud Sitaro". Journal Acta Diurna 3, no. 4, 2014. 
Samovar, Larry A dan Porter, Richard E. Intercultural Communication A Reader. California: Wardsworth Publishing Company, 1976.

Severin, Werner J dan James W. Tankard, Jr. Communication Theories: Origins, Methods and Uses in the Mass Media. New York: Longman, 1992.

Sobur, Alex. Semiotika Komunikasi. Bandung: Remaja Rosdakarya, 2004.

Soekanto, Soerjono. Sosiologi Suatu Pengantar. Jakarta: PT. Raja Grafindo, 1995.

Soyomukti, Nurani. Pengantar Sosiologi. Yogyakarta: Ar Ruzz Media, 2010.

Tubbs, L. Stewart dan Sylvia, Moss. Human Communication I \& II. Terj. Deddy Mulyana. Bandung: Remaja Rosdakarya, 1994.

Tylor, Edwart, Burnett. Primitive Culture: Researches Into The Development of Mythology, Philosophy, Religion, Art, and Custom. New York: Gordon Press, 1974.

Wenburg, John $\mathrm{R}$ dan William W. Wilmot. The Personal Communication Process. New York: John Wiley \& Sons, 1973.

West, Richard dan Lynn H. Turner. Pengantar Teori Komunikasi: Analisis dan Aplikasi. Terj. Maria Natalia Damayanti Maer. Jakarta: Salemba Humanika, 2008.

www.desabuko.com 